\title{
Surface elevation changes on Lachman Crags ice caps (north-eastern Antarctic Peninsula) since 1979 indicated by DEMs and ICESat data
}

\author{
ZBYNĚK ENGEL, ${ }^{1}$ JAN KROPÁČEK, ${ }^{2}$ JANA SMOLÍKOVÁ ${ }^{1}$ \\ ${ }^{1}$ Department of Physical Geography and Geoecology, Charles University, Faculty of Science, Praha, Czech Republic \\ ${ }^{2}$ Department of Applied Geoinformatics and Spatial Planning, Czech University of Life Sciences, Faculty of Environmental \\ Sciences, Praha, Czech Republic \\ Correspondence: Zbyněk Engel <engel@natur.cuni.cz>
}

\begin{abstract}
The long-term warming on the Antarctic Peninsula in the second half of the 20th century prompted rapid retreat of glaciers on the peninsula and surrounding islands. Retreat accelerated until the beginning of the new millennium when the regional warming trend significantly decreased. The response of glaciers to the change in temperature trend has been observed around the northern part of the Antarctic Peninsula but the timing of the shift from the surface lowering to mass gain remains unclear. Using historical aerial photographs, DEMs and satellite altimeter data from ICESat, we estimate areal and surface elevation changes of two small ice caps in the northern part of James Ross Island over the last 39 years. The glacierized area on Lachman Crags decreased from $4.337 \pm 0.037$ to $3.581 \pm 0.014$ $\mathrm{km}^{2}(-17.4 \%)$ between 1979 and 2006 and then increased to $3.597 \pm 0.047 \mathbf{k m}^{2}(0.4 \%)$ until 2016. Surface lowering observed on ice caps after 1979 continued at least until 2008 as indicated by the ICESat data. The change from the lowering trend to increase in glacier surface elevation probably occurred after the ablation season 2008/09, which ranks among the warmest summers in the north-eastern Antarctic Peninsula since the mid-20th century.
\end{abstract}

KEYWORDS: Antarctic glaciology, climate change, ice cap, ice thickness measurements, laser altimetry

\section{INTRODUCTION}

The Antarctic Peninsula (AP) and the sub-Antarctic islands around its northern tip represent a large glacierized area with numerous glaciers and ice caps outside the Antarctic ice sheet. Most of these glaciers are considered to be in retreat and losing mass, but available glaciological observations are sparse and regionally biased. Changes in length, area, volume or mass were determined only for fraction of the local glaciers, and the AP is ranked among poorly sampled regions (Mernild and others, 2013; Zemp and others, 2015). Most regional studies of glacier volume/mass changes have used topographic elevation data derived from stereoscopic aerial photographs (Rivera and others, 2005b; Molina and others, 2007; Engel and others, 2012; Kunz and others, 2012; Osmanoğlu and others, 2014; Pẹtlicki and others, 2017) and satellite imagery (Rückamp and others, 2011; Davies and others, 2012; da Rosa and others, 2015; Fieber and others, 2018), both of which have limited vertical resolution and time coverage. Since the beginning of 21 st century, in situ glaciological monitoring programmes have been initiated to determine the mass balance of small ice caps and glaciers around the AP. In summer 1999-2000, mass-balance measurements started on Bahía del Diablo Glacier on Vega Island on the eastern side of the AP (Fig. 1), with data having been reported to the World Glacier Monitoring Service (WGMS). Additional monitoring programmes were initiated on Livingston Island (Navarro and others, 2013) and King George Island (e.g., Sobota and others, 2015; Mavlyudov, 2016), South Shetland Islands (SSI), $130 \mathrm{~km}$ north-west of the northern tip of the AP. Recently, a surface mass-balance (SMB) record has been reported for small glaciers on James Ross Island (JRI) on the eastern side of the AP (Engel and others, 2018). Nevertheless, the WGMS database contains massbalance data only for three glaciers from the AP region.

The AP belongs to the regions that experienced the largest atmospheric warming on Earth over the second half of 20th century. The mean annual air temperature increased by $\sim 0.5^{\circ} \mathrm{C} /$ decade around the AP (Turner and others, 2005), causing the collapse of ice shelves along its western and north-eastern coast (Cook and Vaughan, 2010) and accelerating the retreat of glaciers (Davies and others, 2012; Scambos and others, 2014) and ice sheets (Wouters and others, 2015). The temperature increase decelerated at the beginning of the new millennium as indicated by a significant decrease in the warming trends reported from the AP region (e.g., Turner and others, 2016). Recent analyses of temperature records from JRI (Ambrožová and Láska, 2016) and the northern AP (Oliva and others, 2017) have even shown that the regional warming trend turned to a cooling during 1999-2015. The response of glaciers to the change in the temperature trend has been observed in the northern part of the AP (Oliva and others, 2017 and references therein) but the timing of the shift from predominantly negative annual SMB to mass gains remains unclear. The first indication of the change in the mass-balance trends over the northern AP was reported by Navarro and others (2013) for Hurd and Johnsons glaciers on Livingston Island (SSI) for the mass-balance year 2008. A later onset of the net mass gain was observed subsequently in the glaciological record for Bellingshausen Ice Dome on King George Island (SSI), which experienced a positive annual SMB in 2010 


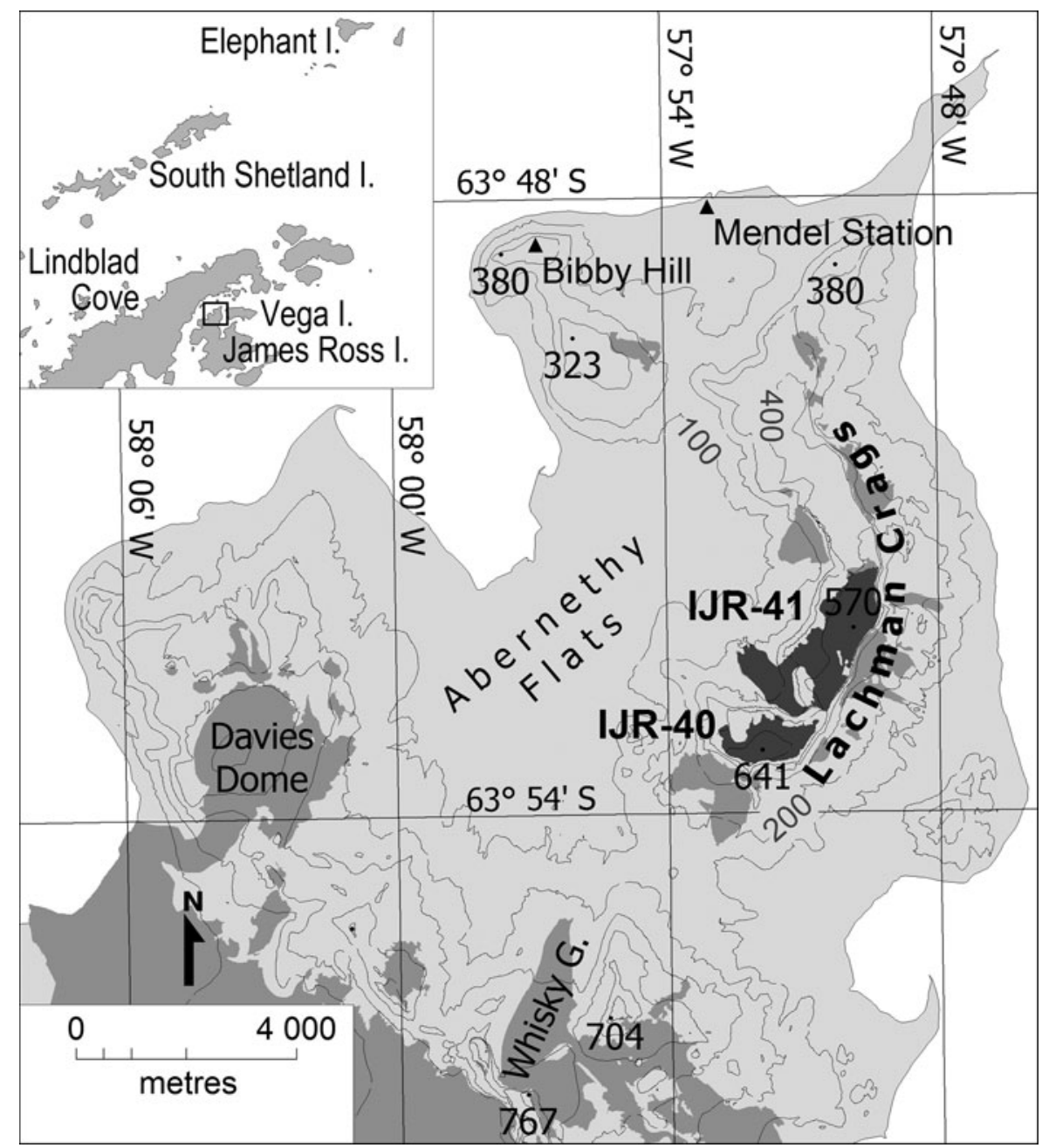

Fig. 1. Location of glaciers (medium grey) and investigated ice caps (dark grey) on Lachman Crags in the northern part of James Ross Island. The inset shows the location of the study area in the north-eastern part of the Antarctic Peninsula.

(Mavlyudov, 2014). The later timing of the shift was proved by the mass-balance dataset for Bahía del Diablo Glacier on Vega Island (Marinsek and Ermolin, 2015), which represents the north-eastern part of the AP. The recently published data from Whisky or Lookalike Glacier (cf. CGS, 2009; SCAR, 2019) and Davies Dome on JRI (Fig. 1) have confirmed predominantly positive annual SMB since the massbalance year 2010 (Engel and others, 2018) but the time coverage of the data precludes the determination of a possible earlier shift in the mass-balance trend.

In order to determine the possible earlier initiation of the annual mass gain on JRI, we analyse the 1979 and 2006 digital elevation models (DEMs) and the Ice Cloud and Land Elevation Satellite (ICESat) data. The satellite altimetry data provide the information on the surface elevation changes of the IJR-41 ice cap on Lachman Crags (LC) plateau in the northern part of JRI (Fig. 1) over the period 2003-2008. The DEMs based on 1979 and 2006 aerial photographs collected by the British Antarctic Survey (BAS) allow us to analyse the surface elevation changes on this ice cap back to 1979. Moreover, we use the ICESat data, DEMs and static Differential Global Navigation Satellite System (DGNSS) measurement for ICESat ground tracks to access the recent trends in the surface elevation changes on the ice cap. Finally, we determine glacier ice thickness along ICESat tracks using the ground penetrating radar
(GPR) and we estimate the time of complete ice decay based on the ice thickness data and observed the rate of glacier surface lowering.

\section{STUDY AREA}

JRI is situated on the eastern flank of the northern part of the AP. The island extends between $63^{\circ} 46^{\prime}$ and $64^{\circ} 27^{\prime} \mathrm{S}$, and reaches $1600 \mathrm{~m}$ at the summit of Mount Haddington. The glacial cover of JRI consists of the Mount Haddington ice cap, minor ice caps and outlets at its periphery and small individual glaciers on the Ulu Peninsula in the northern part of the island. The surface of the peninsula is distinguished by cliff-bounded plateaux landforms rising up to $\sim 600 \mathrm{~m}$ a.s.l. The prominent flat-topped forms (mesas) are controlled by the bedrock geology, with the late Neogene basalt lava flows forming resistant caps on a Cretaceous sedimentary strata (Hambrey and others, 2008). These mesas are interpreted as the remnants of voluminous lava-fed deltas sourced from a vent at Mount Haddington stratovolcano (Smellie and others, 2008). The LC consists of the thickest lava caprock of any delta on JRI (Smellie and others, 2008), and it dominates the landscape of the north-eastern part of the Ulu Peninsula (Figs 1, 2).

The western side of LC borders low-angle slopes to the Abernethy Flats rising from $\sim 30$ to $380-600 \mathrm{~m}$ a.s.l. 


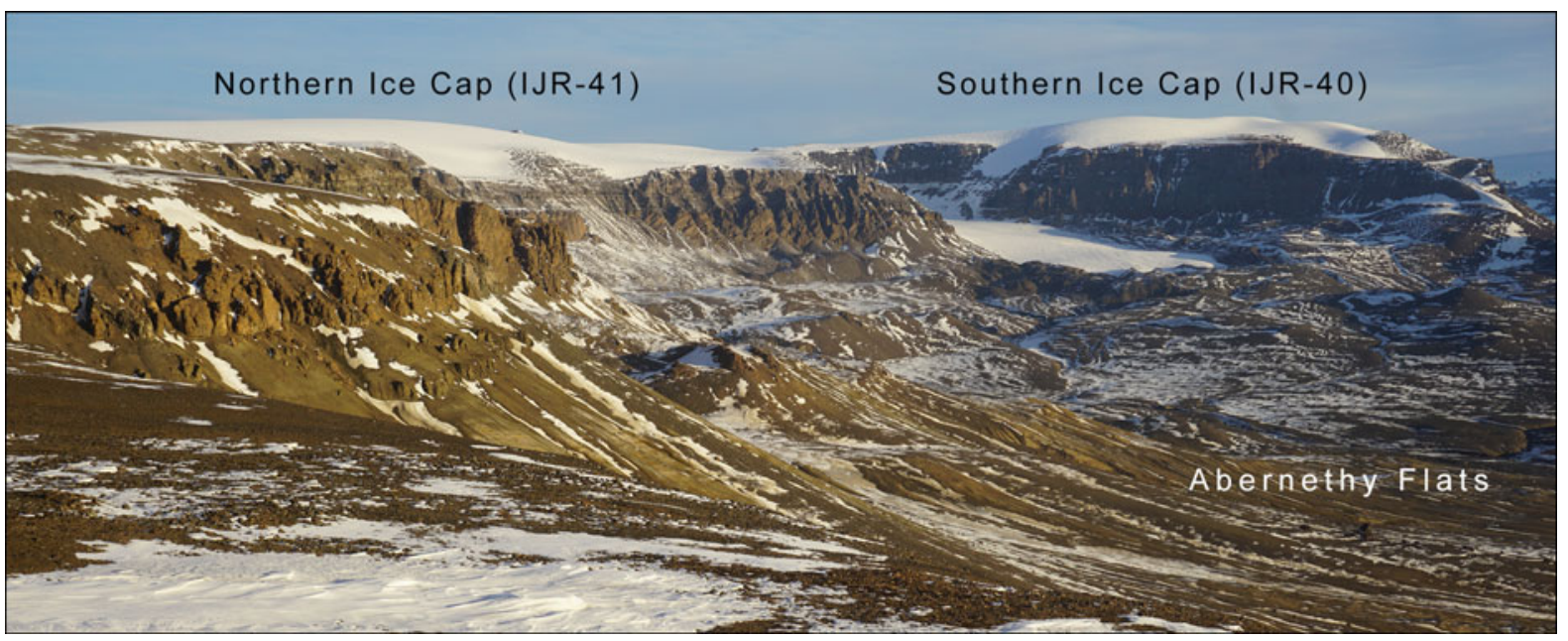

Fig. 2. View of the western side of Lachman Crags from the north-west. Photograph taken on 10 March 2018 from the southern tip of Johnson Mesa.

(Fig. 2). This side is mantled with extensive scree and numerous protalus ramparts that are missing only in sections where two small glaciers descend from the steep cliffs of LC. Scree slopes and protalus ramparts are also formed along the northwestern face of LC, east of two abandoned cirques with a steep headwall and overdeepened basins. The eastern and southern face of LC is distinctly different from the western slopes. The straight margin of the LC is sharply delimited by vertical cliffs, which increase in height towards the south from $\sim 130$ to $300 \mathrm{~m}$. Perennial snow banks and protalus ramparts lie at the foot of a lower northern section of the face, while large mass movement blocks, glaciers and rock glaciers dominate along the higher part of LC. The mass movement blocks separated from the mesa form chaotic hummocky terrain that descends in steps to the seashore.

The surface of LC is inclined to the north, descending from $600 \mathrm{~m}$ a.s.l. at its southern tip to $380 \mathrm{~m}$ a.s.l. at the northern end. The northern part of the mesa (380-430 m a.s.I.) is icefree and its flat surface is covered with blockfields and sorted polygon nets. Seasonal snow cover is effectively transported from its surface by the prevailing south-westerly winds (Hrbáček and others, 2016), feeding perennial snow fields and glaciers in the lee-side of the mesa. Two ice caps cover the southern part of LC (Fig. 2). A larger ice cap (referred as IJR-41 in the inventory by Rabassa and others, 1982) is elongated in the NNE direction being $2.8 \mathrm{~km}$ long $\left(63^{\circ} 51^{\prime} 34^{\prime \prime}-63^{\circ}\right.$ $53^{\prime} 2^{\prime \prime} \mathrm{S}, 57^{\circ} 49^{\prime} 17^{\prime \prime}-57^{\circ} 52^{\prime} 29^{\prime \prime} \mathrm{W}$ ) and having an area of 2.7 $\mathrm{km}^{2}$. A prominent south-west facing outlet drains the central part of the IJR-41 ice cap with a flat top at $571 \mathrm{~m}$ a. s.l. This outlet joins a small glacier snout, which forms a large cirque between the IJR-41 and IJR-40 ice caps. The snout flows towards north-west and terminates at the elevation of 196 m a.s.I. A smaller IJR-40 ice cap with an area of $0.9 \mathrm{~km}^{2}$ covers the southernmost part of LC $\left(63^{\circ} 53^{\prime} 2^{\prime \prime}-63^{\circ}\right.$ $\left.53^{\prime} 31^{\prime \prime} \mathrm{S}, 57^{\circ} 50^{\prime} 40^{\prime \prime}-57^{\circ} 52^{\prime} 50^{\prime \prime} \mathrm{W}\right)$. It is located at the elevation of $470-649 \mathrm{~m}$ a.s.l. and its $2.3 \mathrm{~km}$ long axis has the ENE direction. Both ice caps represent an accumulation area of small stagnant glaciers, which are located below the eastern face of the mesa. These glaciers are detached from the ice caps and thus gain mass due to the snowdrift from the ice caps by winds. San José and Lachman (IJR-38) glaciers at the foot of the southern face of LC and Triangular glacier in its western slope are less influenced by the wind-driven snow redistribution.
The climate of JRI is influenced by the 1000-1800 $\mathrm{m}$ high orographic barrier of the AP (King and others, 2003) and the Southern Annular Mode (Marshall and others, 2006). A positive trend in this annular mode increases north-westerly air flow over the AP and amplifies warming on the eastern side of the AP due to the föhn effect (Grosvenor and others, 2014). The mean annual air temperatures (2005-15) in the northern part of $\mathrm{JRI}$ range from $-7.0^{\circ} \mathrm{C}$ at the sea level (Mendel Base, $10 \mathrm{~m}$ a.s.l.) to lower than $-8.0^{\circ} \mathrm{C}$ (Bibby Hill, 375 m a.s.l.) in higher-elevated regions (Ambrožová and Láska, 2016). Positive air temperatures over the short summer season (2-3 months) cause snow and ice to melt on glaciers, these effects vary strongly in response to cloudiness and solar radiation. The modelled annual precipitation is estimated between 200 and $500 \mathrm{~mm}$ w.e. (van Lipzig and others, 2004). Since the mid-20th century, snowfall and summer melt intensity has significantly increased (Abram and others, 2013; Medley and Thomas, 2019).

\section{DATA AND METHODS}

The BAS aerial photographs taken in 1979 and 2006 and WorldView-2 images from 2016 (Table 1) were used to extract information for an extent of investigated glaciers. The aerial photograph-based DEMs produced by the GEODIS company (the Czech Republic) were used to estimate ice elevations and thinning rates over the glacier surface between 1979 and 2006. The dataset has rms errors of $2.0 \mathrm{~m}$ in both the horizontal and vertical directions (1979) and $0.7 \mathrm{~m}$ horizontally and $0.8 \mathrm{~m}$ vertically (2006), respectively (Meixner, 2009). The accuracy of DEMs derived by stereo-processing over glaciers often suffers from a lack of surface patterns resulting in poor quality elevation information (Rivera and others, 2005a). We checked the original aerial photographs and found sufficient surfacepatterned textures on the glacier surface. We thus assume that the DEM quality over glaciers is not lower than over the rest of the dataset. Surface elevation changes and annual thinning rates after 2006 were calculated using the 2006 DEM and the Reference Elevation Model of Antarctica (REMA) created by the Polar Geospatial Center (PGC, 2018). REMA was constructed from high-resolution $(\sim 0.5 \mathrm{~m})$ stereoscopic imagery collected by DigitalGlobe, Inc. constellation of optical imaging satellites (PGC, 2018). 
Table 1. Summary of remote-sensing data

\begin{tabular}{lllr}
\hline Acquisition date & Camera/spacecraft & Images/bands & Pixel size at ground m \\
\hline January 1979 & Vinten $70 \mathrm{~mm}$ & panchromatic & 2.1 \\
February 14 2006 & Leica RC30 & panchromatic & 0.52 \\
December 3 2016 & WorldView-2 & Pan-MS1-MS2 & BAS/RN/1/79 \\
& & & 0.61 \\
\hline
\end{tabular}

This model portrays first-return elevation values that reflect temporally variable conditions such as snow cover. Snow depth records and field observations on the Ulu Peninsula indicate irregular distribution of snow cover, with a maximum depth of fresh snow ranging from $0.3 \mathrm{~m}$ at the sea level (Hrbáček and others, 2016) to $\sim 0.6 \mathrm{~m}$ on glaciers. The effect of variable snow depth on the accuracy of the DEMs cannot be excluded but it remains on the order of magnitude lower than vertical uncertainty of DEM-derived elevation values. Glacier-elevation changes on the flat top surface of IJR-41 ice cap were estimated in more detail using the available DEMs, ICESat data acquired during the period 2003-2008 and in situ DGNSS measurements from 2018.

The ground track of ICESat satellite crosses LC providing elevation measurements of land surface above the TOPEXPoseidon ellipsoid along the satellite ground track each $172 \mathrm{~m}$. Each point measurement corresponds to a footprint with $70 \mathrm{~m}$ in diameter. Due to energy management constraints, the laser was on during limited periods only, mainly in March, May and October. The ground tracks are fixed but single flyovers do not follow exactly the same line on the surface. In order to derive the change in ice surface elevation for small glaciers, ICESat elevations are related to a static elevation reference such as SRTM DEM (e.g., Gardner and others, 2013; Neckel and others, 2014). We used the static DGNSS measurements at the ICESat footprints as a reference that increases the accuracy of the determined elevation compared with the DEM reference (Kropáček and others, 2014). We used the geodetic records of GLA14 product release 34 . The surface elevation was determined at 72 individual locations spread along six ICESat ground tracks over $\sim 2 \mathrm{~km}$ on the ice dome. Erroneous measurements due to clouds were identified by the elevation threshold of $100 \mathrm{~m}$ and removed.

DGNSS technology was applied to determine the contemporary ice surface elevation for the ICESat ground tracks. The data for 72 points were collected during a field campaign in January 2018 using a Trimble Geo7X roving station (Trimble Navigation Limited, 2013). The reading lasted $3 \mathrm{~min}$ at each site to obtain centimetre accuracy after post-processing. The coordinate points were corrected in relation to the base station mounted on a stable surface near the J.G. Mendel Czech Antarctic Station $\left(63^{\circ} 48^{\prime} \mathrm{S} ; 57^{\circ} 53^{\prime} \mathrm{W}\right)$ and the correction data acquired by the German Antarctic Receiving Station at the Chilean station General Bernardo O'Higgins $\left(63^{\circ} 19^{\prime} \mathrm{S} ; 57^{\circ} 54^{\prime} \mathrm{W}\right)$. The data collected on LC ice cap were post-processed for differential correction using the Trimble GPS Pathfinder Office software.

GPR was used to determine the ice thickness for ground tracks (55 points) of ICESat on IJR-41 ice cap. The GPR data were collected in February 2017 along five parallel profiles on the dome (Fig. 3). GPR profiling was carried out using an unshielded $50 \mathrm{MHz}$ Rough Terrain Antenna and RAMAC CU-II control unit (MALÅ GeoScience, 2005). The scan spacing was set to $0.1 \mathrm{~s}$ and the GPR was man-hauled at a mean speed of $\sim 3 \mathrm{~km} \mathrm{~h}^{-1}$, yielding one radar trace every $\sim 0.01 \mathrm{~m}$. A Garmin GPSMAP 60CSx receiver (Garmin International, 2007) was used to determine the coordinates for the corresponding trace numbers with the horizontal position accuracy $<5 \mathrm{~m}$. The GPR data were processed and interpreted using the ReflexW software version 8.5 (Sandmeier, 2017). Two-way travel times to depths were converted assuming a radio-wave velocity of $168 \mathrm{~m} \mathrm{\mu s}^{-1}$ reported by Narod and Clarke (1994) for cold glacier ice. The raw GPR profiles were filtered using an automatic gain function (AGC-Gain), background removal and static (topographic) correction. The glacier bed was selected on radargrams by a phase follower tool in ReflexW. The automatic assignment of picks was controlled and eventually redirected to the desired phase at the glacier bed. The picks were collected only for the bed reflections that can be clearly identified in the radargrams.

The uncertainty of ice thickness determined for ICESat points was estimated following the approach proposed by Lapazaran and others (2016), who describes the error in thickness (i) retrieved from the GPR measurement and (ii) due to the incorrect horizontal positioning of the measurement point. For the calculations of the first uncertainty component, we considered a conservative estimate of vertical resolution (a half of the signal's wavelength in ice, i.e.

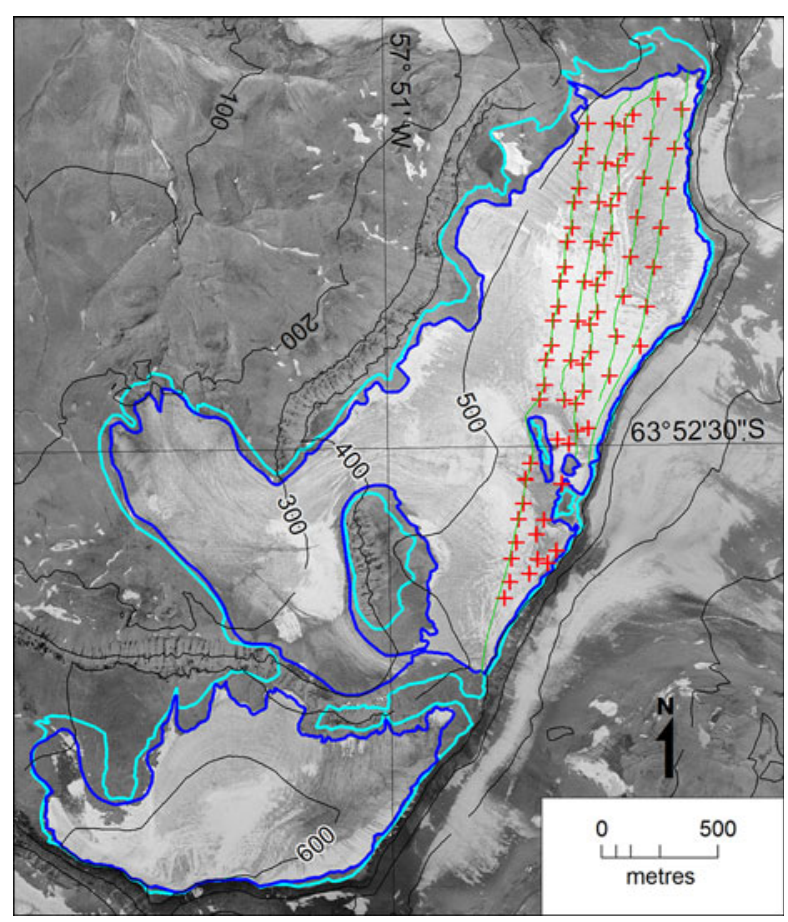

Fig. 3. Ground tracks of ICESat (red crosses) and GPR profiles (green lines) on the flat-topped surface of IJR- 41 ice cap superimposed on an aerial photography acquired in February 2006. Light and dark blue lines represent the glacierized area in 1979 and 2017, respectively. 
$1.68 \mathrm{~m}$ for the $50 \mathrm{MHz}$ antenna) and a relative error in radiowave velocity of $2.4 \%$, which corresponds to a range of velocity values from 166 to $170 \mathrm{~m} \mathrm{\mu s}^{-1}$. We chose this relatively narrow range since we anticipated only minor variations in ice and snow characteristics (density, water/air content) on the investigated part of LC ice cap (500-570 m a.s.I.). The positioning-related ice-thickness error was determined from the variability of ice thickness along and across the profiling direction. Taking into account that the radar traces were positioned using uncorrected GPS data, we evaluated the maximum absolute value of the differences between the value at the ICESat point and the neighbouring values within a circle with a radius of $5 \mathrm{~m}$. The variability of ice thickness along and across the profiling direction was calculated from the values picked for radar traces and interpolated between GPR profiles, respectively.

\section{RESULTS}

The area and ice-surface elevation changes determined for the investigated glaciers are given in Table 2. A single ice cap with the area of $4.337 \pm 0.037 \mathrm{~km}^{2}$ covered LC in 1979. Its surface decreased significantly before 2006, losing $17.4 \%$ of its area. Assuming a constant rate of change, the ice cap therefore lost $0.029 \mathrm{~km}^{2} \mathrm{a}^{-1}$ during the period 1979-2006. Most of the measured areal loss occurred at the southern part of LC at 450-600 m a.s.I. (Fig. 3). As a result, ice cover on LC diverged on two separate ice caps with the area of $2.709 \pm 0.009$ and $0.872 \pm 0.004 \mathrm{~km}^{2}$ on the central and southern parts of $\mathrm{LC}$, respectively. From 2006 to 2016, the surface area of the larger of the two ice caps (IJR-41) remained almost the same. The glacier decreased to $2.674 \pm 0.031 \mathrm{~km}^{2}$, losing only $1.3 \%$ of its area at a mean rate of $0.003 \mathrm{~km}^{2} \mathrm{a}^{-1}$. By contrast, the surface area of IJR-40 increased to $0.922 \pm 0.015 \mathrm{~km}^{2}$ over the same period, gaining $5.8 \%$ of its area at a mean rate of $0.005 \mathrm{~km}^{2} \mathrm{a}^{-1}$.

The glacierized area on LC has experienced only minor surface elevation changes since 1979. The surface lowering observed along western margin of the glaciers was partly compensated by an increase in surface elevation above $560 \mathrm{~m}$. Between 1979 and 2006, the mean surface elevation of IJR-41 ice cap decreased by $7.3 \pm 2.2 \mathrm{~m}$, at a mean rate of $-0.28 \mathrm{~m} \mathrm{a}^{-1}$ (Table 2). By contrast, the mean surface elevation of IJR-40 ice cap increased by $5.6 \pm 2.2 \mathrm{~m}$, with a mean rate of $0.21 \mathrm{~m} \mathrm{a}^{-1}$. The discrepancy in surface elevation changes may be attributed to the recession of the lower-elevated periphery of IJR-40 ice cap and more prominent accumulation on its upper part that is situated $\sim 70 \mathrm{~m}$ higher than the top of IJR-41. Both ice caps experienced an increase in surface elevation over the period 2006-2015. Mean surface elevations of IJR-41 and IJR-40 ice caps increased on average by $3.9 \pm 0.8$ and $1.2 \pm 0.8 \mathrm{~m}$, respectively. On average, mean surface elevations increased at a rate of 0.43 and $0.13 \mathrm{~m} \mathrm{a}^{-1}$.

The elevation data determined at 72 individual ICESat points document surface elevation changes on the flat top part of IJR-41 ice cap over the period 1979-2018 (Table 3). The mean surface elevation of the dome decreased by 4.0 $\mathrm{m}$ between 1979 and 2006 at a mean lowering rate of $-0.1 \mathrm{~m} \mathrm{a}^{-1}$. Only the highest part of the dome (26 out of 72 ICESat points) experienced an increase in surface elevation by $3.7 \mathrm{~m}$ on average over this period. From 2006 to 2015, the surface elevation of the dome increased on average by $4.0 \mathrm{~m}$ (a mean rate of $0.4 \mathrm{~m} \mathrm{a}^{-1}$ ) with an increase observed at 63 points. Since 2015, the dome surface has returned to the lowering trend, which is recorded at all points. From 2015 to 2018, the surface elevation of the dome decreased by $3.7 \mathrm{~m}$ at a mean rate of $-1.2 \mathrm{~m} \mathrm{a}^{-1}$. The surface lowering prevailed on the dome over most of the 1979-2018 as indicated by a net mean decrease value of $3.7 \mathrm{~m}$ and a mean lowering rate of $-0.1 \mathrm{~m} \mathrm{a}^{-1}$. The decreasing trend was also confirmed for the period 20032008 based on the ICESat data (Table 4 and Fig. 4). An overall increase in surface elevation was restricted only to the highest part of the dome (Fig. 5).

The mean glacier ice thickness for 55 points on the flat top surface of IJR-41 ice cap is $43.1 \pm 1.7 \mathrm{~m}$ (Table 3 ). The greatest thickness was observed on the highest part of the dome, where the glacier ice was as much as $71.4 \pm 2.1 \mathrm{~m}$ thick. The ice thickness decreases slowly towards the northern glacier margin, which terminates on the slightly inclined bedrock at the central part of the LC mesa (Figs 6, 7). The thickness decreases more abruptly in the southern part of the dome where steep bedrock outcrops protrude above ice surface (Fig. 6). In the west-east direction, greater ice thickness values (up to $60 \mathrm{~m}$ ) were recorded along the western ICESat ground tracks. This part of the dome represents a source area for two lobes that descend towards the western margin of the ice cap. The ice thickness ranges from 10 to $40 \mathrm{~m}$ along the eastern margin of the dome, which forms an ice-cliff above the basalt and hyaloclastite

Table 2. Changes of surface area and elevation of ice caps on Lachman Crags since January 1979

\begin{tabular}{|c|c|c|c|c|}
\hline \multirow[b]{2}{*}{ Year } & \multicolumn{2}{|l|}{ Surface area $\mathrm{km}^{2}$} & \multicolumn{2}{|l|}{ Mean elevation $\mathrm{m}$ a.s.l. } \\
\hline & IJR-41 & IJR-40 & IJR-41 & IJR-40 \\
\hline \multirow[t]{2}{*}{1979} & \multicolumn{2}{|c|}{$4.337 \pm 0.037$} & \multicolumn{2}{|c|}{$490.3 \pm 10.4$} \\
\hline & $3.219 \pm 0.027$ & $1.117 \pm 0.012$ & $457.4 \pm 10.3$ & $585.4 \pm 6.1$ \\
\hline 2006 & $2.709 \pm 0.009$ & $0.872 \pm 0.004$ & $450.1 \pm 10.7$ & $591.0 \pm 5.6$ \\
\hline $\begin{array}{l}2016^{*} \\
1979-2006\end{array}$ & $2.674 \pm 0.031$ & $0.922 \pm 0.015$ & $454.0 \pm 10.7$ & $592.2 \pm 5.7$ \\
\hline Change & $-0.511 \pm 0.028(-15.9 \%)$ & $-0.245 \pm 0.013(-21.9 \%)$ & $-7.3 \pm 2.2(-1.6 \%)$ & $5.6 \pm 2.2(+1.0 \%)$ \\
\hline $\begin{array}{l}\text { Mean annual change } \\
\text { 2006-2016 }\end{array}$ & $-0.020 \pm 0.001(-0.6 \%)$ & $-0.0094 \pm 0.0005(-0.8 \%)$ & $-0.28 \pm 0.08(-0.06 \%)$ & $0.21 \pm 0.08(+0.04 \%)$ \\
\hline Change & $-0.035 \pm 0.033(-1.3 \%)$ & $0.050 \pm 0.016(+5.8 \%)$ & $3.9 \pm 0.8(+0.9 \%)$ & $1.2 \pm 0.8(+0.2 \%)$ \\
\hline Mean annual change & $-0.003 \pm 0.003(-0.1 \%)$ & $0.005 \pm 0.001(+0.5 \%)$ & $0.43 \pm 0.09(+0.1 \%)$ & $0.13 \pm 0.09(+0.02 \%)$ \\
\hline
\end{tabular}

* Mean elevation determined for 2015 (PGC, 2018). 
Table 3. Summary of elevation data and ice thickness at ICESat points. A dash indicates unknown ice thickness at points that were not covered with GPR survey. The decay time of ice is determined from the surface-lowering trend observed during the period 1979-2018 (Trend 1) and 2015-2018 (Trend 2)

\begin{tabular}{|c|c|c|c|c|c|c|c|c|c|c|c|c|}
\hline \multirow{2}{*}{$\begin{array}{l}\text { Date of ICESat } \\
\text { tracks }\end{array}$} & \multirow[b]{2}{*}{ Latitude $\left({ }^{\circ} \mathrm{S}\right)$} & \multirow[b]{2}{*}{ Longitude $\left({ }^{\circ} \mathrm{W}\right)$} & \multicolumn{5}{|c|}{ Elevation $\mathrm{m}$ a.s.l. } & \multirow{2}{*}{$\begin{array}{l}\text { Ice } \\
\text { thickness m }\end{array}$} & \multicolumn{2}{|l|}{$\begin{array}{l}\text { Elevation } \\
\text { change } \mathrm{m} \mathrm{a}^{-1}\end{array}$} & \multicolumn{2}{|c|}{$\begin{array}{l}\text { Ice decay } \\
\text { time y }\end{array}$} \\
\hline & & & 2003-2008 & 1979 & 2006 & 2015 & 2018 & & 1979-2018 & 2015-2018 & Trend 1 & Trend 2 \\
\hline $6-11-2003$ & 63.862376 & 57.832055 & 498.4 & 509.6 & 511.8 & 501.6 & 496.9 & $7.4 \pm 1.9$ & -0.33 & -1.55 & 22 & 5 \\
\hline $6-11-2003$ & 63.863897 & 57.832702 & 521.8 & 532.5 & 517.8 & 522.8 & 517.4 & $19.6 \pm 1.6$ & -0.40 & -1.80 & 50 & 11 \\
\hline 6-11-2003 & 63.865419 & 57.833352 & 534.8 & 548.2 & 532.0 & 538.0 & 534.0 & $37.0 \pm 1.5$ & -0.37 & -1.33 & 99 & 28 \\
\hline $6-11-2003$ & 63.866942 & 57.834003 & 543.4 & 555.1 & 542.7 & 549.1 & 545.3 & $47.8 \pm 1.7$ & -0.26 & -1.25 & 185 & 38 \\
\hline $6-11-2003$ & 63.868465 & 57.834655 & 556.1 & 560.0 & 552.7 & 560.3 & 556.5 & $59.5 \pm 1.5$ & -0.09 & -1.25 & 644 & 47 \\
\hline $6-11-2003$ & 63.869989 & 57.835308 & 564.3 & 561.6 & 558.7 & 568.0 & 564.2 & $61.8 \pm 2.1$ & 0.07 & -1.28 & - & 48 \\
\hline $6-11-2003$ & 63.871514 & 57.835963 & 564.9 & 560.6 & 560.8 & 568.6 & 564.4 & $58.5 \pm 1.9$ & 0.10 & -1.40 & - & 42 \\
\hline $6-11-2003$ & 63.873039 & 57.836619 & 553.1 & 554.7 & 548.6 & 556.5 & 552.2 & $31.4 \pm 1.9$ & -0.06 & -1.41 & 483 & 22 \\
\hline $6-11-2003$ & 63.876090 & 57.837932 & 522.2 & 523.0 & 523.6 & 527.9 & 523.6 & - & 0.02 & -1.42 & - & 19 \\
\hline $6-11-2003$ & 63.877611 & 57.838587 & 531.6 & 538.4 & 532.4 & 536.1 & 532.8 & - & -0.15 & -1.09 & 267 & 36 \\
\hline 6-11-2003 & 63.879131 & 57.839240 & 542.3 & 550.0 & 540.0 & 545.3 & 541.7 & - & -0.22 & -1.18 & 217 & 40 \\
\hline $6-11-2003$ & 63.880651 & 57.839895 & 539.3 & 545.9 & 535.6 & 541.2 & 537.1 & - & -0.23 & -1.38 & 199 & 33 \\
\hline $8-6-2004$ & 63.862075 & 57.828092 & 524.3 & 529.5 & 533.9 & 523.6 & 519.1 & $28.5 \pm 1.1$ & -0.28 & -1.52 & 103 & 19 \\
\hline $8-6-2004$ & 63.863592 & 57.828757 & 542.3 & 548.0 & 541.1 & 540.9 & 536.4 & $40.6 \pm 1.7$ & -0.30 & -1.51 & 133 & 27 \\
\hline $8-6-2004$ & 63.865110 & 57.829424 & 551.4 & 557.2 & 546.7 & 550.3 & 546.3 & $34.7 \pm 1.1$ & -0.29 & -1.33 & 121 & 26 \\
\hline $8-6-2004$ & 63.866632 & 57.830093 & 557.8 & 560.0 & 555.2 & 557.9 & 554.6 & $56.8 \pm 1.8$ & -0.14 & -1.10 & 398 & 52 \\
\hline $8-6-2004$ & 63.868155 & 57.830762 & 565.5 & 560.0 & 561.5 & 567.5 & 564.1 & $51.4 \pm 1.9$ & 0.11 & -1.13 & - & 46 \\
\hline $8-6-2004$ & 63.869680 & 57.831428 & 571.7 & 560.0 & 565.0 & 574.3 & 571.0 & $64.7 \pm 2.4$ & 0.29 & -1.09 & - & 60 \\
\hline $8-6-2004$ & 63.871206 & 57.832089 & 571.9 & 559.4 & 565.0 & 575.0 & 572.0 & $64.1 \pm 1.6$ & 0.33 & -0.97 & - & 66 \\
\hline $8-6-2004$ & 63.872733 & 57.832739 & 562.6 & 554.3 & 558.9 & 566.1 & 562.7 & $60.3 \pm 2.1$ & 0.22 & -1.12 & - & 54 \\
\hline $8-6-2004$ & 63.874261 & 57.833385 & 548.7 & 552.0 & 545.9 & 550.0 & 546.3 & $22.8 \pm 2.9$ & -0.15 & -1.23 & 153 & 19 \\
\hline $8-6-2004$ & 63.878844 & 57.835318 & 539.8 & 545.5 & 535.8 & 538.6 & 535.6 & - & -0.26 & -0.99 & 16 & 4 \\
\hline $11-3-2005$ & 63.878212 & 57.837057 & 540.7 & 549.4 & 539.2 & 542.2 & 539.5 & - & -0.26 & -0.93 & 76 & 21 \\
\hline 11-3-2005 & 63.879741 & 57.837715 & 543.5 & 550.0 & 540.0 & 545.0 & 541.4 & - & -0.23 & -1.20 & 82 & 16 \\
\hline $10-6-2005$ & 63.863353 & 57.832229 & 516.2 & 529.8 & 518.5 & 517.6 & 511.9 & $17.8 \pm 1.4$ & -0.47 & -1.90 & 38 & 9 \\
\hline $10-6-2005$ & 63.864879 & 57.832884 & 531.7 & 545.2 & 533.5 & 534.8 & 530.5 & $27.8 \pm 2.2$ & -0.39 & -1.45 & 72 & 19 \\
\hline $10-6-2005$ & 63.866401 & 57.833539 & 541.6 & 554.7 & 541.5 & 546.5 & 542.6 & $43.2 \pm 1.7$ & -0.32 & -1.29 & 136 & 34 \\
\hline $10-6-2005$ & 63.867921 & 57.834196 & 552.9 & 557.7 & 550.9 & 557.5 & 553.7 & $56.3 \pm 1.6$ & -0.11 & -1.25 & 531 & 45 \\
\hline $10-6-2005$ & 63.869439 & 57.834852 & 563.4 & 560.0 & 558.7 & 566.6 & 562.9 & $59.8 \pm 1.6$ & 0.08 & -1.25 & - & 48 \\
\hline $10-6-2005$ & 63.870955 & 57.835508 & 566.6 & 564.2 & 564.7 & 570.2 & 566.4 & $55.6 \pm 1.5$ & 0.06 & -1.28 & - & 44 \\
\hline $10-6-2005$ & 63.872470 & 57.836164 & 558.9 & 557.7 & 555.6 & 563.7 & 560.1 & $51.6 \pm 2.2$ & 0.06 & -1.23 & - & 42 \\
\hline $10-6-2005$ & 63.875495 & 57.837475 & 524.1 & 530.4 & 522.6 & 530.2 & 525.4 & - & -0.13 & -1.59 & 113 & 9 \\
\hline $10-6-2005$ & 63.877006 & 57.838129 & 528.1 & 531.0 & 526.5 & 533.1 & 529.3 & - & -0.04 & -1.25 & 895 & 31 \\
\hline $10-6-2005$ & 63.878517 & 57.838780 & 540.3 & 548.5 & 537.9 & 542.4 & 539.3 & - & -0.24 & -1.04 & 169 & 39 \\
\hline $10-6-2005$ & 63.880028 & 57.839430 & 542.8 & 548.7 & 540.0 & 545.1 & 541.3 & - & -0.20 & -1.30 & 259 & 39 \\
\hline $11-11-2005$ & 63.862504 & 57.828822 & 526.1 & 534.8 & 535.7 & 527.3 & 522.3 & $28.8 \pm 1.0$ & -0.33 & -1.67 & 88 & 17 \\
\hline $11-11-2005$ & 63.864028 & 57.829463 & 542.5 & 550.2 & 540.7 & 542.9 & 538.5 & $35.2 \pm 1.4$ & -0.31 & -1.44 & 115 & 24 \\
\hline $11-11-2005$ & 63.865555 & 57.830109 & 551.2 & 558.2 & 548.9 & 551.6 & 547.9 & $45.6 \pm 1.3$ & -0.27 & -1.26 & 168 & 36 \\
\hline 11-11-2005 & 63.867085 & 57.830762 & 557.8 & 560.0 & 555.4 & 560.2 & 557.1 & $63.5 \pm 2.1$ & -0.08 & -1.03 & 839 & 61 \\
\hline 11-11-2005 & 63.868620 & 57.831424 & 566.2 & 560.0 & 564.2 & 569.7 & 566.4 & $48.9 \pm 1.5$ & 0.17 & -1.10 & - & 45 \\
\hline $11-11-2005$ & 63.870155 & 57.832091 & 572.0 & 560.0 & 565.0 & 575.1 & 571.9 & $66.7 \pm 2.2$ & 0.31 & -1.04 & - & 64 \\
\hline 11-11-2005 & 63.871690 & 57.832759 & 570.0 & 558.9 & 565.0 & 573.8 & 570.8 & $64.2 \pm 1.7$ & 0.31 & -0.98 & - & 65 \\
\hline 11-11-2005 & 63.873223 & 57.833427 & 559.0 & 554.5 & 555.0 & 562.4 & 559.4 & $50.6 \pm 2.2$ & 0.13 & -1.01 & - & 50 \\
\hline $11-11-2005$ & 63.874751 & 57.834092 & 542.0 & 550.0 & 541.6 & 544.6 & 541.2 & - & -0.23 & -1.13 & 28 & 6 \\
\hline $11-11-2005$ & 63.876276 & 57.834754 & 538.4 & 544.6 & 536.3 & 543.4 & 540.2 & - & -0.12 & -1.07 & 0 & 0 \\
\hline 11-11-2005 & 63.879317 & 57.836069 & 541.3 & 547.5 & 537.5 & 541.2 & 537.6 & - & -0.26 & -1.21 & 21 & 5 \\
\hline 14-6-2006 & 63.861890 & 57.823792 & 519.1 & 526.6 & 529.8 & 521.8 & 518.7 & $9.3 \pm 1.3$ & -0.21 & -1.02 & 45 & 9 \\
\hline 14-6-2006 & 63.863411 & 57.824456 & 533.3 & 540.8 & 542.7 & 535.0 & 531.0 & $12.7 \pm 1.6$ & -0.26 & -1.31 & 50 & 10 \\
\hline 14-6-2006 & 63.864932 & 57.825120 & 542.8 & 549.8 & 542.1 & 543.9 & 539.7 & $25.9 \pm 1.8$ & -0.27 & -1.42 & 97 & 18 \\
\hline $14-6-2006$ & 63.866452 & 57.825781 & 547.9 & 556.2 & 548.1 & 549.4 & 546.1 & $25.9 \pm 1.3$ & -0.27 & -1.12 & 98 & 23 \\
\hline $14-6-2006$ & 63.867969 & 57.826437 & 555.6 & 560.0 & 552.0 & 557.9 & 555.1 & $40.8 \pm 1.4$ & -0.13 & -0.94 & 316 & 43 \\
\hline 14-6-2006 & 63.869486 & 57.827091 & 561.3 & 560.0 & 557.5 & 563.5 & 560.7 & $36.5 \pm 2.0$ & 0.02 & -0.93 & - & 39 \\
\hline 14-6-2006 & 63.871003 & 57.827741 & 560.0 & 544.4 & 556.8 & 562.8 & 559.8 & $37.8 \pm 2.9$ & 0.41 & -0.97 & - & 39 \\
\hline 23-10-2007 & 63.861468 & 57.825878 & 516.3 & 524.3 & 522.9 & 521.4 & 517.1 & $10.8 \pm 1.2$ & -0.19 & -1.45 & 57 & 7 \\
\hline 23-10-2007 & 63.862994 & 57.826537 & 535.3 & 542.6 & 543.4 & 537.7 & 533.5 & $32.5 \pm 1.7$ & -0.24 & -1.40 & 135 & 23 \\
\hline $23-10-2007$ & 63.864518 & 57.827191 & 545.8 & 554.5 & 543.4 & 548.2 & 543.7 & $35.4 \pm 1.1$ & -0.28 & -1.52 & 124 & 23 \\
\hline $23-10-2007$ & 63.866041 & 57.827843 & 551.8 & 560.0 & 550.3 & 554.9 & 550.5 & $38.6 \pm 1.6$ & -0.25 & -1.47 & 155 & 26 \\
\hline 23-10-2007 & 63.867564 & 57.828494 & 559.5 & 560.0 & 557.8 & 562.8 & 559.4 & $47.9 \pm 1.4$ & -0.02 & -1.14 & 2828 & 42 \\
\hline 23-10-2007 & 63.869087 & 57.829144 & 566.9 & 560.0 & 564.7 & 570.1 & 567.3 & $47.8 \pm 1.4$ & 0.19 & -0.96 & - & 50 \\
\hline 23-10-2007 & 63.870613 & 57.829795 & 568.7 & 557.0 & 564.5 & 572.1 & 569.0 & $58.6 \pm 2.2$ & 0.32 & -1.04 & - & 56 \\
\hline $23-10-2007$ & 63.872141 & 57.830447 & 560.6 & 551.3 & 556.9 & 565.3 & 562.0 & $53.4 \pm 1.7$ & 0.28 & -1.10 & - & 49 \\
\hline $9-3-2008$ & 63.862391 & 57.829889 & 512.4 & 526.2 & 532.0 & 518.4 & 512.7 & $25.3 \pm 0.9$ & -0.35 & -1.89 & 72 & 13 \\
\hline
\end{tabular}


Table 3. (Cont.)

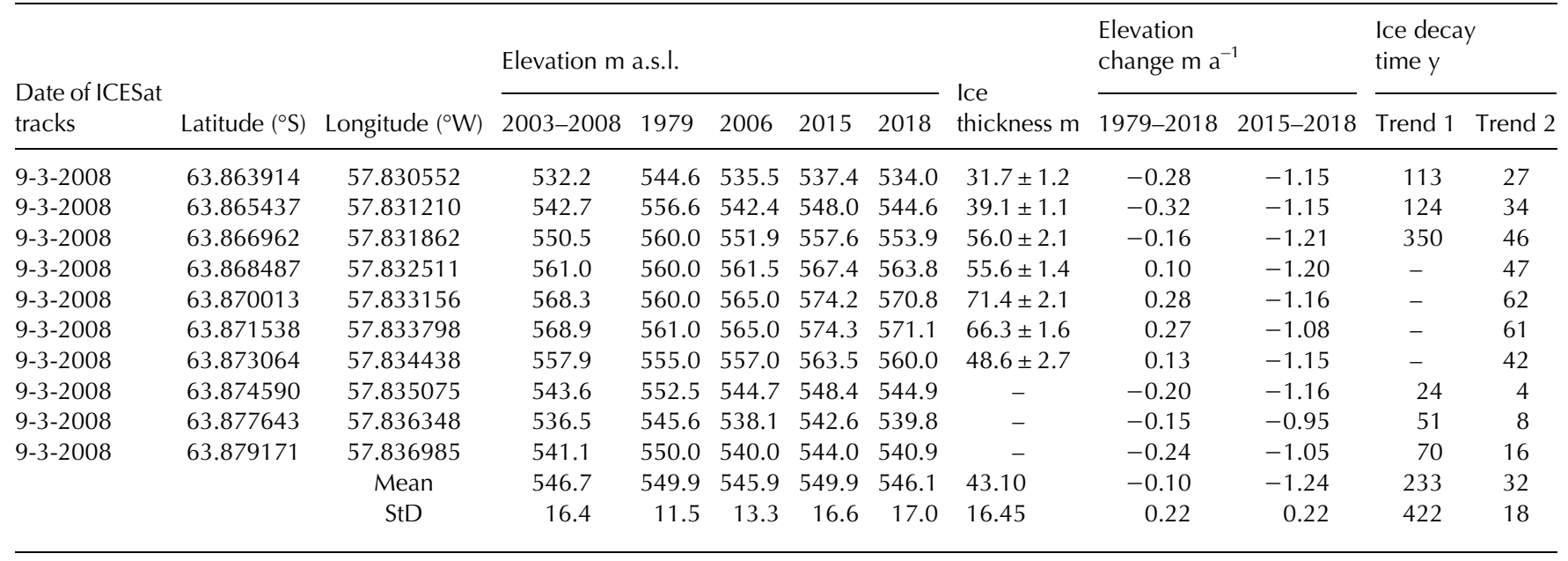

eastern face of LC. The uncertainties in the ice-thickness values related to the GPR measurement and trace-positioning range from 0.22 to $1.70 \mathrm{~m}$ and from 0.42 to $2.84 \mathrm{~m}$, respectively. The total uncertainties range between 0.93 and 2.89 $\mathrm{m}$, with a mean value of $1.71 \mathrm{~m}$ and a std dev. of $0.44 \mathrm{~m}$.

\section{DISCUSSION}

The decrease in the surface area of the ice caps on LC over the 1979-2006 period is within the range of values reported by Engel and others (2012) for small glaciers in the northern part of JRI. The areal loss of 21.9 and $15.9 \%$ observed on IJR40 and IJR-41 ice caps, respectively, coincides with the $22.1 \%$ decrease of Davies Dome surface area (Engel and others, 2012). These values are higher than the $10.6 \%$ loss reported by Engel and others (2012) for Whisky Glacier, which suggests a more rapid retreat of ice caps than coldbased valley glaciers in this region. This implies higher sensitivity of small ice caps to regional climate settings and local meteorological conditions (e.g., Nesje and others, 2008; Zekollari and others, 2017). The recession of the ice caps in the northern part of JRI is less prominent compared with Subantarctic (sensu Cogley and others, 2014) ice caps and their outlets that experience up to an order of magnitude higher retreat and surface-lowering rates (Table 5).

The deceleration of the retreat rate and the increase in surface elevation observed on the investigated ice caps during the 2006-2015 period correspond with the lowered

Table 4. List of ICESat ground tracks showing the difference of ICESat elevations with respect to the DGNSS measurements from 2018 as median value for each track

\begin{tabular}{|c|c|c|c|c|}
\hline Track date & $\begin{array}{l}\text { Number } \\
\text { of points }\end{array}$ & $\begin{array}{l}\text { Median } \\
\text { elevation } \\
\text { difference }(\mathrm{m})\end{array}$ & $\begin{array}{l}\text { Standard } \\
\text { deviation } \\
\text { from mean } \\
\text { value }\end{array}$ & $\begin{array}{l}\text { Standard } \\
\text { deviation } \\
\text { from median } \\
\text { value }\end{array}$ \\
\hline 06 Nov 2003 & 12 & 0.50 & 1.65 & 1.65 \\
\hline 08 Jun 2004 & 10 & 2.80 & 2.17 & 2.17 \\
\hline 11 Mar 2005 & 2 & 1.73 & 0.45 & 0.45 \\
\hline 10 Jun 2005 & 11 & 0.22 & 1.62 & 1.62 \\
\hline 11 Nov 2005 & 11 & 0.65 & 2.01 & 2.08 \\
\hline 14 Jun 2006 & 7 & 0.59 & 1.08 & 1.27 \\
\hline 23 Oct 2007 & 8 & -0.10 & 1.20 & 1.27 \\
\hline 09 Mar 2008 & 11 & -2.14 & 1.09 & 1.11 \\
\hline
\end{tabular}

glacier recession around the northern AP (Table 5). Positive mass-balance values recorded in this region since the glaciological year 2009/10 (Mavlyudov, 2016; Engel and others, 2018; WGMS, 2018) and the low rates of glacier recession in subsequent years (Pẹtlicki and others, 2017; Pudełko and others, 2018) have been attributed to the deceleration of the regional warming trend and the decrease in summer temperature (Navarro and others, 2013; Lirio and others, 2017; Oliva and others, 2017). The cooling trend in the northern AP has been recently confirmed by Ambrožová and Láska (2016), who found the most prominent decrease in air temperature $\left(1.44^{\circ} \mathrm{C} /\right.$ decade $)$ over the period 20052015 in the northern part of JRI. Moreover, this re-assessment of the temperature records has revealed a significant decrease in summer temperature at AP meteorological stations including Mendel and Bibby Hill stations near LC.

Although glaciers in the AP are influenced by a set of regional and local climatic conditions (e.g., Arigony-Neto and others, 2014), our results confirm the relationship between summer mean air temperatures and surface elevation changes reported by Skvarca and De Angelis (2003) for this region. Surface elevation changes on IJR-41 ice cap indicated by the ICESat data correlate with summer temperatures at Esperanza meteorological station during the period 2003-2008 (Fig. 8). The lowering trend observed on IJR-41 ice cap during the period 2003-2008 (Fig. 4) and surface elevation changes determined from the ICESat tracks measured in June 2006, October 2007 and March 2008 suggest that the

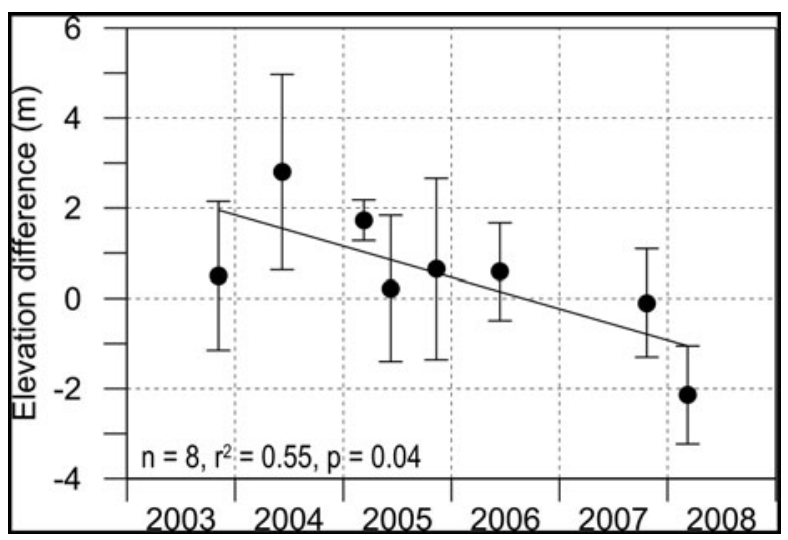

Fig. 4. Median elevation difference of the ICESat tracks with respect to the DGNSS reference. 


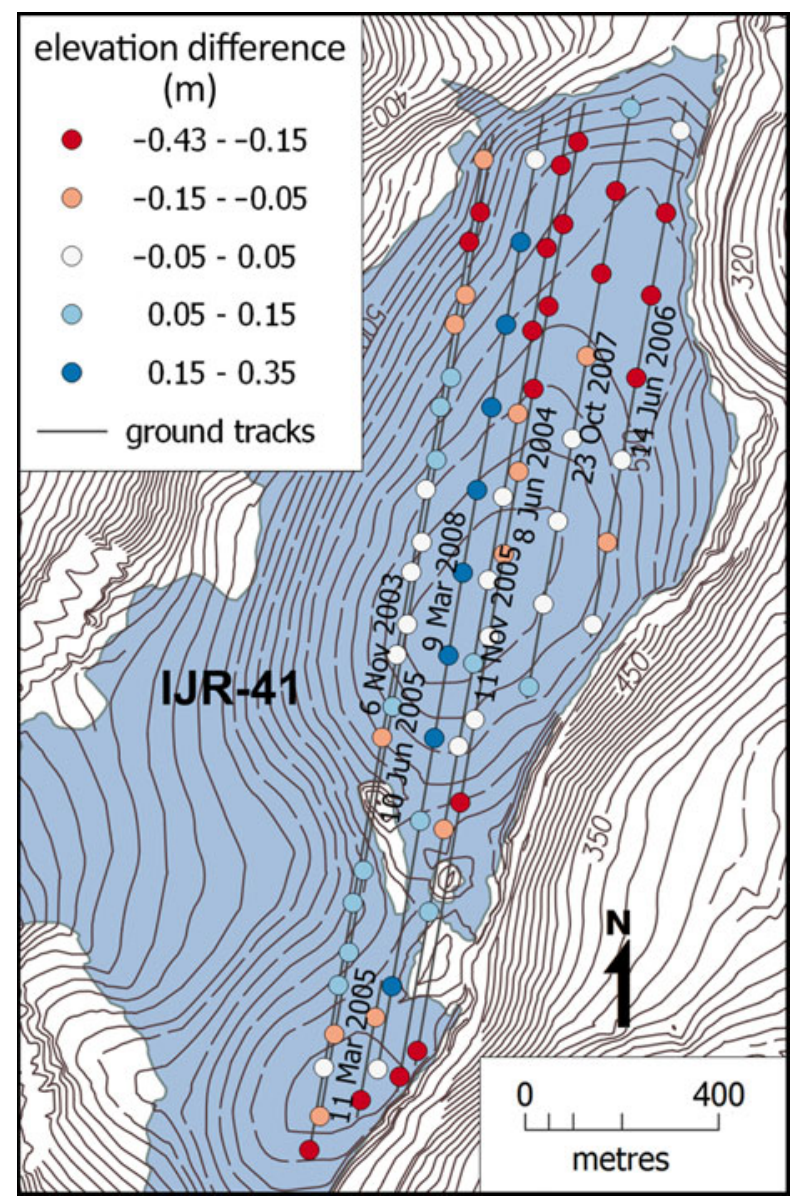

Fig. 5. Median annual difference of ice surface elevation between the ICESat data (2003-2008) and DGNSS (2018) measurements. glacier lost mass in the mass-balance year 2008. High temperatures recorded in the northern AP during the ablation season 2007/08, which has been the fifth warmest summer (with a mean summer air temperature of $1.7^{\circ} \mathrm{C}$ ) on Esperanza since 1953 according to the Reference Antarctic Data for Environmental Research (READER) database (Turner and others, 2004) supports this view. An increase in surface elevation on the dome in the mass-balance year 2009 cannot be excluded based on the ICESat data as the last available tracks represent the onset of this year. However, warm conditions during the ablation season 2008/09 $\left(1.6^{\circ} \mathrm{C}\right.$ on Esperanza; READER database) and negative SMB reported for the glaciers around the AP (Fig. 9) make this possibility improbable.

Based on the mean lowering rates and ice thickness determined for 55 points on IJR-41 ice cap, we calculate the time for the complete melting of glacier ice at these points. The melting time must be considered as a rough estimate because the approximation omits future changes in climate conditions and ice dynamics. In order to reflect recent temporal variability of the glacier evolution, we take into account the mean lowering rates for the periods 19792018 and 2015-2018. The surface elevation changes over a longer time span range from $+0.41 \mathrm{~m} \mathrm{a}^{-1}$ at the southeastern part of the dome to $-0.47 \mathrm{~m} \mathrm{a}^{-1}$ near the northwestern ice margin. The calculated ice decay times indicate that the periphery of the ice cap north of the small western outlet will disappear within decades (Fig. 7). The same evolution may be expected near the bedrock outcrops in the southern part of the dome. The melting time increases to centuries towards the central part of the dome that would gain mass under unchanged conditions. The accelerated lowering rates $\left(-0.93\right.$ to $\left.-1.90 \mathrm{~m} \mathrm{a}^{-1}\right)$ observed over the period $2015-$

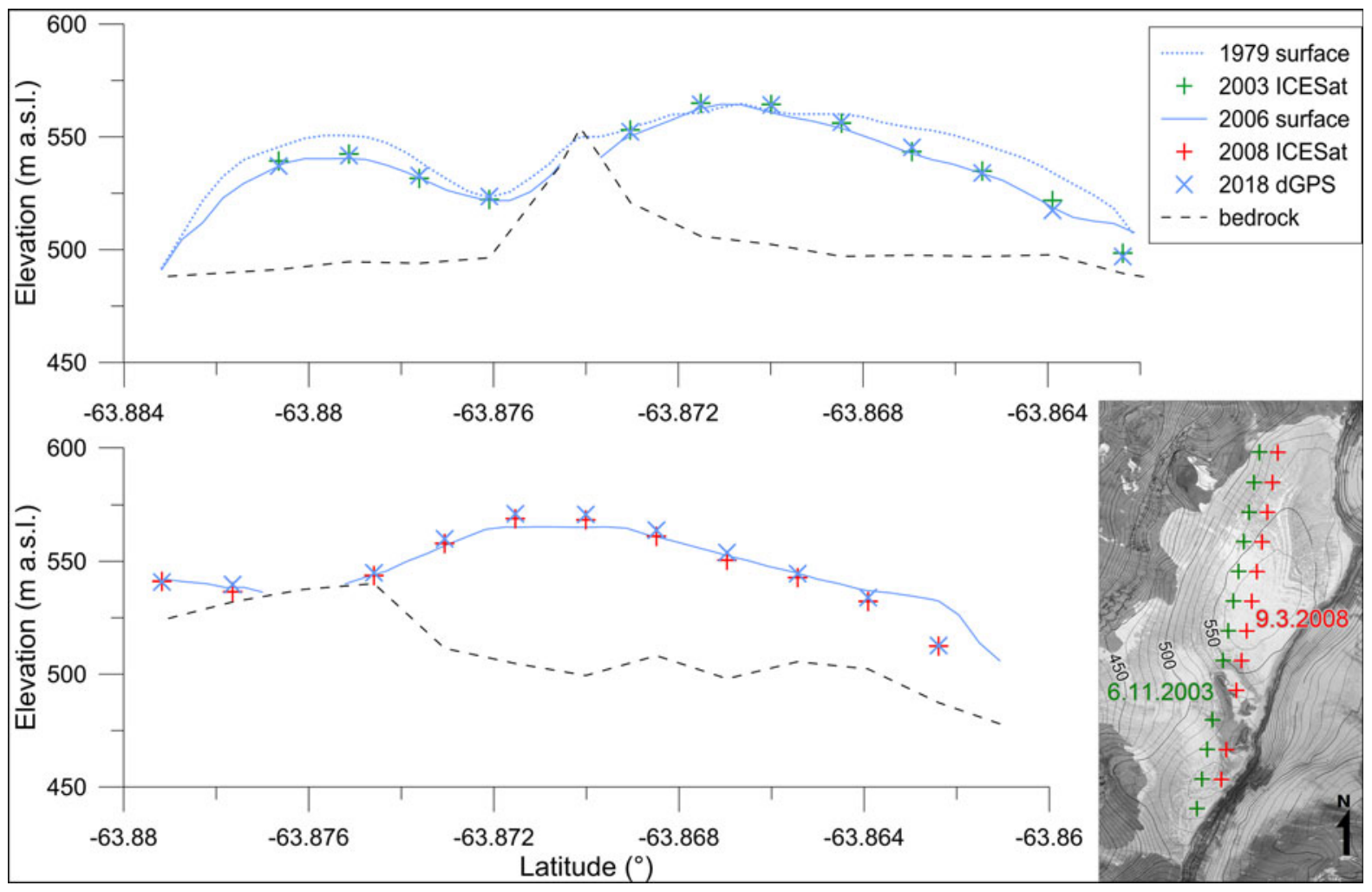

Fig. 6. Glacier-surface elevation changes derived from the DEMs, ICESat data and DGNSS measurement on IJR-41 ice cap. The vertical axis is exaggerated by a factor of 4 . 


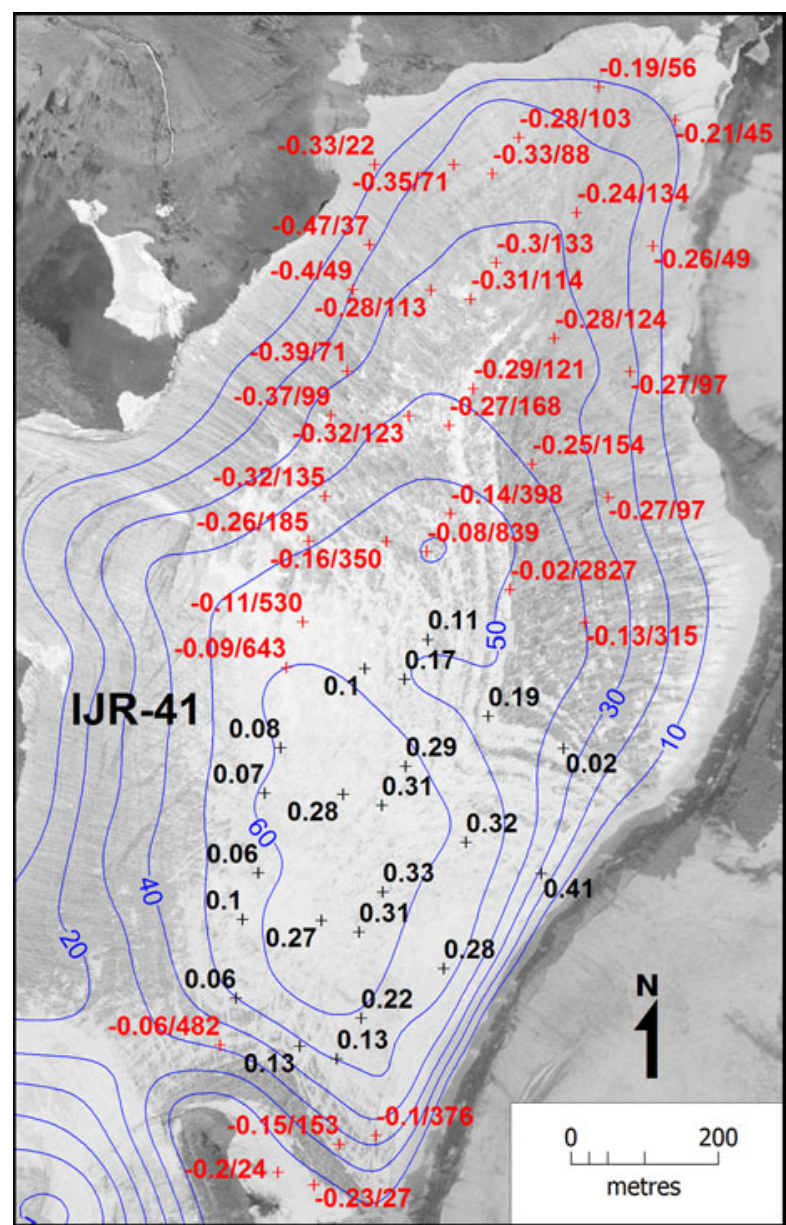

Fig. 7. Ice thickness (blue lines) on the dome and glacier-surface elevation changes $\left(\mathrm{m} \mathrm{a}^{-1}\right)$ at ICESat points (red crosses) over the period 1979-2018. Black figures show the increase in surface elevation while red values indicate surface lowering and years to complete ice melt based on the averaged lowering rates over this period.
2018 reduce the time to complete ice decay roughly by an order of magnitude. If these rates are taken into account, even the highest part of the ice cap would disappear in 66 \pm 19 years.

The future evolution of ice around the highest part of the dome approximately based on the mean lowering rate for the period 1979-2018 is consistent with the ice-decay estimates reported for glaciers of comparable area in the northern AP region. The estimated melting time of Whisky Glacier and Davies Dome on the Ulu Peninsula is $104 \pm 5$ and $228 \pm 22$ years, respectively (Engel and others, 2012). Similarly, Bellingshausen Dome on SSI is predicted to disappear in 285 years if the present warming trend persists (Rückamp and others, 2011). A total decay of IJR-41 ice cap within the next few decades estimated based on the accelerated lowering rate (2015-2018) seems to be unrealistic. A rapid ice-decay during this time span is predicted for small glaciers at low elevation that are located in regions affected by changes in regional atmospheric circulation. Simões and others (2004) described these conditions on the SSI where small glaciers lost up to $83 \%$ of their area during the second half of the 20th century. Rapidly receding glaciers that are now close to decay were also reported from South Georgia (Gordon and others, 2008) and the Kerguelen Islands (Berthier and others, 2009).

\section{CONCLUSIONS}

The analyses of the DEMs, ICESat and DGNSS data revealed a predominant retreat of ice caps on LC since 1979. Between 1979 and 2006, the glacierized area decreased by $17.4 \%$ at a mean rate of $0.03 \mathrm{~km}^{2} \mathrm{a}^{-1}$. The observed areal decrease, retreat rate and surface elevation change are in accordance with the values that represent glacier recession in the northern part of JRI, which are by an order of magnitude lower than the values reported for ice caps and outlets on the Subantarctic islands. The glacier retreat on LC decelerated

Table 5. Mean area and surface elevation changes of ice caps and outlet glaciers along the northern part of the Antarctic Peninsula

\begin{tabular}{|c|c|c|c|c|c|c|c|c|c|c|}
\hline \multirow[b]{2}{*}{ Site } & \multicolumn{2}{|l|}{ Glacier } & \multirow[b]{2}{*}{ Period } & \multicolumn{4}{|c|}{ Area change } & \multicolumn{2}{|c|}{ Elevation change } & \multirow[b]{2}{*}{ Reference } \\
\hline & Name & Type & & $\mathrm{km}^{2}$ & $\%$ & $\mathrm{~km}^{2} \mathrm{a}^{-1}$ & $\%$ & $\mathrm{~m}$ & $\mathrm{~m} \mathrm{a}^{-1}$ & \\
\hline \multirow[t]{2}{*}{ Elephant Island } & Doyle & O-m & 1957-2014 & - & - & - & - & -9.1 & -0.16 & \multirow[t]{2}{*}{ Fieber and others, 2018} \\
\hline & Helava & O-m & 1957-2014 & - & - & - & - & -2.1 & -0.04 & \\
\hline \multirow[t]{5}{*}{ James Ross Island } & Davies Dome & IC-m & 1979-2006 & -1.840 & -22.1 & -0.071 & -0.8 & -8.5 & -0.33 & \multirow{4}{*}{$\begin{array}{l}\text { Engel and others, } 2012 \\
\text { this study }\end{array}$} \\
\hline & IJR-40 & IC-I & 1979-2006 & -0.245 & -21.9 & -0.009 & -0.8 & +5.6 & +0.21 & \\
\hline & \multirow[t]{2}{*}{ IJR-40 } & \multirow[t]{2}{*}{ IC-I } & 1979-2006 & -0.511 & -15.9 & -0.020 & -0.6 & -7.3 & -0.28 & \\
\hline & & & 2006-2016 & -0.035 & -1.3 & -0.003 & -0.1 & +3.9 & +0.43 & \\
\hline & Whisky & $\mathrm{V}$ & 1979-2006 & -0.284 & -10.6 & -0.011 & -0.4 & -10.1 & -0.39 & Engel and others, 2012 \\
\hline \multirow[t]{7}{*}{ King George Island } & Bellingshausen Dome & IC-I & 1998-2009 & - & - & - & - & - & $\begin{array}{l}-0.20 \text { to } \\
-1.44\end{array}$ & Rückamp and others, 2011 \\
\hline & Ecology & O-m & 1979-2001 & - & - & - & - & -38.4 & -1.75 & Pętlicki and others, 2017 \\
\hline & Ecology/Sphinx & O-m/l & 1979-2007 & -3.195 & -38.0 & -0.114 & -1.4 & - & - & \multirow{2}{*}{$\begin{array}{l}\text { Sobota and others, } 2015 \\
\text { da Rosa and others, } 2015\end{array}$} \\
\hline & Wanda & O-I & 1979-2011 & -0.710 & -31.3 & -0.022 & -1.0 & - & - & \\
\hline & \multirow[t]{2}{*}{ Warszawa Icefield } & \multirow[t]{2}{*}{ IC } & 1979-2007 & -4.810 & -24.3 & -0.172 & -0.9 & - & - & \multirow[t]{2}{*}{ Pudełko and others, 2018} \\
\hline & & & 1979-2018 & -6.100 & -30.8 & -0.156 & -0.8 & - & - & \\
\hline & Znosko & O-m & 1956-2013 & - & - & - & - & -11.1 & -0.20 & Fieber and others, 2018 \\
\hline Lindblad Cove & Schoeling & O-m & 1957-2014 & - & - & - & - & +1.7 & +0.03 & Fieber and others, 2018 \\
\hline
\end{tabular}

IC, ice cap; $\mathrm{O}$, outlet; $\mathrm{V}$, valley glacier; -I, land-terminating; -m, marine-terminating. 


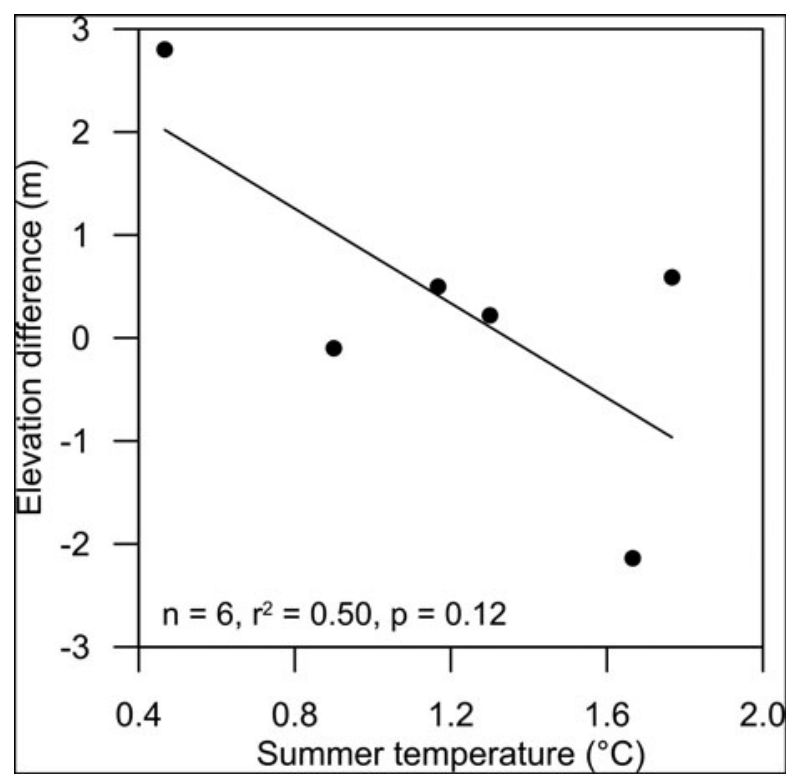

Fig. 8. ICESat tracks/current glacier surface elevation difference vs mean summer (DJF) air temperature on Esperanza meteorological station during the period 2003-2008.

during the period 2006-2016 when the area of IJR-41 ice cap decreased by $1.3 \%$ and IJR-40 experienced a $5.8 \%$ increase in the surface area. The reduced retreat is in line with the recent observations and mass-balance studies of glaciers around the northern AP that show a marked decrease in glacier recession and predominantly positive SMB since the mass-balance year 2009/10.

The ICESat data show that the surface lowering on the IJR41 ice cap prevailed at least until March 2008. The lowering trend indicated by satellite altimetry over the period 20032008 correlates with the mean summer air temperature in the northern AP, implying the significance of surface ablation for annual mass changes of ice caps in this region. The shift from the lowering trend to an increase in glacier surface elevation probably occurred after the ablation season 2008/09, which ranks among the warmest summers in the northeastern AP since the mid-20th century. The onset of the positive surface elevation changes in 2009/10 correlates with the period of surface mass gain that was reported from glaciers around the AP in the period 2009-2015. Since 2015, the IJR-41 ice cap has experienced enhanced lowering as indicated by the DGNSS data.

The observed aerial and surface elevation changes of the investigated glaciers indicate that the ice caps on LC are out of equilibrium with the current climate. If a continuation of the 1979-2018 surface-lowering trend is assumed, the IJR41 ice cap will decay over the next decades to centuries except for the highest part of the dome. According to the 2015-2018 lowering scenario, glacier retreat would occur by an order of magnitude rapidly, and the whole glacier will disappear in $66 \pm 19$ years.

The combination of the historical ICESat data with the present DGNSS measurements has proved to be a valuable tool for improving the interpretation of the surface elevation and mass-balance changes on small ice caps in the AP region. Based on these data, the shift from surface mass loss to mass gain prior to the mass-balance year 2009/10 was excluded on the Ulu Peninsula. The satellite altimetry provides a proxy for surface mass changes on the glacier prior to the initiation of the direct field-based measurements in 2009.

The ICESat data records provide a high-accuracy estimate of glacier surface elevation over the first decade of $21 \mathrm{st}$ century. A combination of the ICESat dataset and groundbased DGNSS measurements excludes terrain information derived from an aerial survey which in polar areas suffers from the lack of an adequate ground control (Fox and Cziferszky, 2008). It thus offers an alternative and independent source of information on glacier thinning in the area of

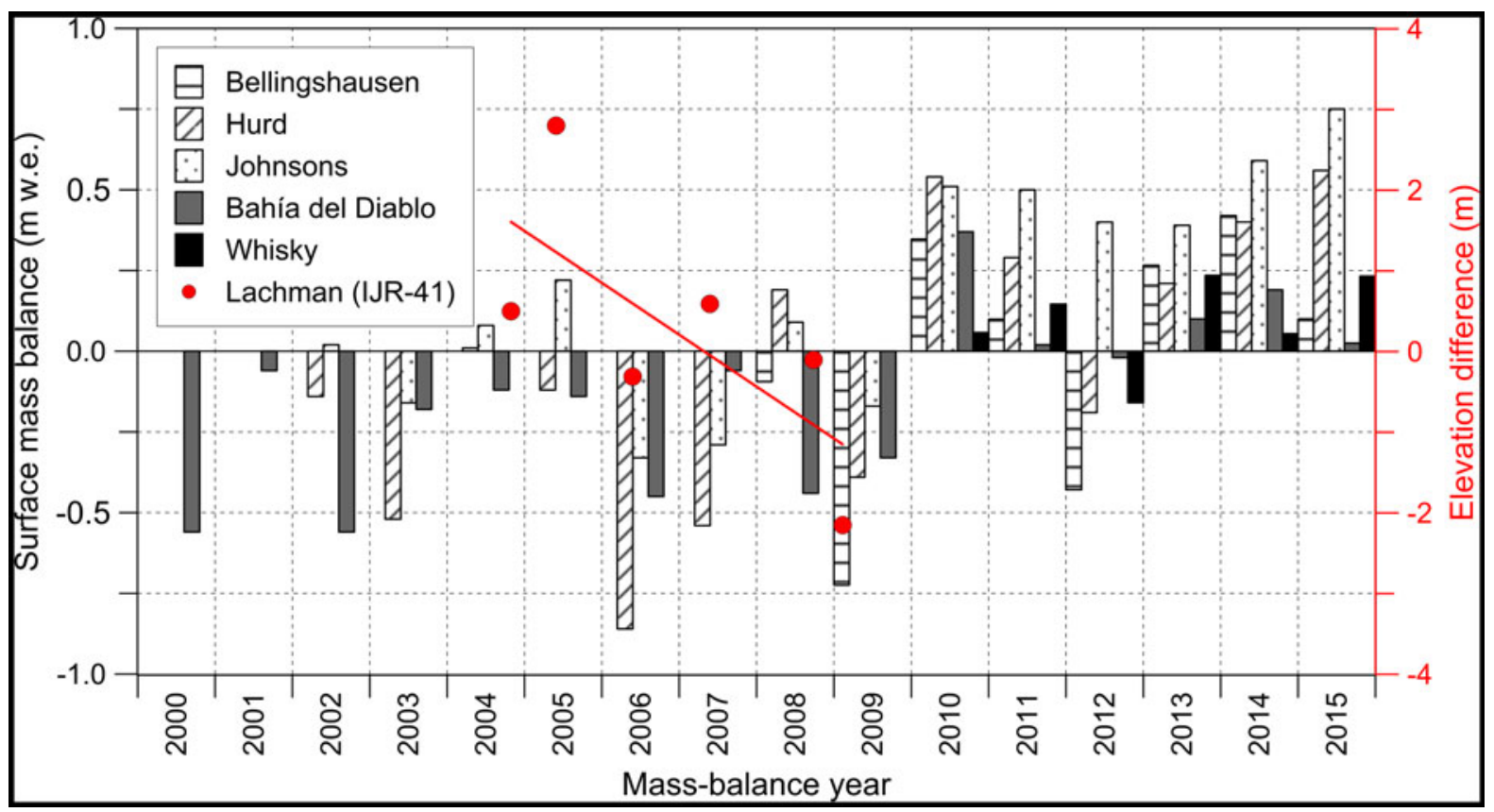

Fig. 9. Surface lowering on IJR-41 ice cap (red dots) during the period 2003-2008 and a change from surface mass loss to mass gain after 2009 as indicated by the ICESat data and mass-balance records for glaciers in the northern part of the Antarctic Peninsula. The right axis indicates the elevation difference between ICESat tracks and current glacier surface. Data adopted from Mavlyudov (2016), Engel and others (2018), WGMS database (2018) and this study. 
the AP. The approach applied in our study is limited to glaciers with low-relief topography, especially ice caps and ice domes, where laser altimetry is not biased by steep slopes and surface undulations (Hilbert and Schmullius, 2012). Moreover, it is not realistic to couple the available ICESat measurements over large areas of the AP with DGNSS survey because fieldwork in the hardly accessible areas within this region can be extremely difficult and expensive. As soon as an accurate and homogeneous DEM will be available for the area, it will be possible to evaluate the ICESat measurements in an accurate way.

\section{ACKNOWLEDGEMENTS}

The authors acknowledge funding from the Czech Science Foundation project (GC16-14122J). Fieldwork was supported by the crew of the J.G. Mendel Station financed by the Ministry of Education, Youth and Sports of the Czech Republic (projects LM2015078 and CZ.02.1.01/0.0/0.0/ 16_013/0001708). We acknowledge the British Antarctic Survey for aerial photographs, the National Snow and Ice Data Center for ICESat data and the Polar Geospatial Center for the Reference Elevation Model of Antarctica. We thank for helpful comments from anonymous referees.

\section{REFERENCES}

Abram NJ and 8 others (2013) Acceleration of snow melt in an Antarctic Peninsula ice core during the twentieth century. Nat. Geosci., 6(5), 404-411 (doi: 10.1038/ngeo1787)

Ambrožová K and Láska K (2016) The Air Temperature Change on James Ross Island within the context of the Antarctic Peninsula. In Nováček A, ed. Sborník príspěvkủ z Výroční konference ČS, 5-7 September 2016. University of South Bohemia, České Budějovice, 20-25, In Czech

Arigony-Neto J and 6 others (2014) Monitoring glacier changes on the Antarctic Peninsula. In Kargel JS, Leonard GJ, Bishop MP, Kääb A and Raup BH, eds. Global land lce measurements from space. Springer, Heidelberg, 717-741 (doi: 10.1007/978-3540-79818-7_30)

Berthier E, Le Bris R, Mabileau L, Testut L and Rémy F (2009) Ice wastage on the Kerguelen Islands $\left(49^{\circ} \mathrm{S}, 69^{\circ} \mathrm{E}\right)$ between 1963 and 2006. J. Geophys. Res., 114, F03005 (doi: 10.1029/2008JF001192)

CGS (2009) James Ross Island - northern part. Topographic map 1: 25 000. Czech Geological Survey, Praha

Cogley JG, Berthier E and Donoghue S (2014) Remote sensing of glaciers of the Subantarctic islands. In Kargel JS, Leonard GJ, Bishop MP, Kääb A and Raup BH, eds. Global land ice measurements from space. Springer, Heidelberg, 759-780 (doi: 10.1007/ 978-3-540-79818-7_32)

Cook AJ and Vaughan DG (2010) Overview of areal changes of the ice shelves on the Antarctic Peninsula over the past 50 years. Cryosphere, 4, 77-98 (doi: 10.5194/tc-4-77-2010)

da Rosa KK and 5 others (2015) Recent changes in the Wanda Glacier, King George Island, Antarctica. Pesqui. Geoci., 42(2), 187-196

Davies BJ, Carrivick JL, Glasser NF, Hambrey MJ and Smellie JL (2012) Variable glacier response to atmospheric warming, northern Antarctic Peninsula, 1988-2009. Cryosphere, 6, 10311048 (doi: 10.5194/tc-6-1031-2012)

Engel Z, Nývlt D and Láska K (2012) Ice thickness, areal and volumetric changes of Davies Dome and Whisky Glacier (James Ross Island, Antarctic Peninsula) in 1979-2006. J. Glaciol., 58 (211), 904-914 (doi: 10.3189/2012JoG11J156)

Engel Z, Láska K, Nývlt D and Stachoň Z (2018) Surface mass balance of small glaciers on James Ross Island, north-eastern Antarctic Peninsula, during 2009-2015. J. Glaciol., 64(245), 349-361 (doi: 10.1017/jog.2018.17)
Fieber KD and 5 others (2018) Rigorous 3D change determination in Antarctic Peninsula glaciers from stereo WorldView-2 and archival aerial imagery. Remote Sens. Environ., 205, 18-31 (doi: 10.1016/j.rse.2017.10.042)

Fox AJ and Cziferszky A (2008) Unlocking the time capsule of historic aerial photography to measure changes in Antarctic Peninsula glaciers. Photogramm. Rec., 23(121), 51-68 (doi: 10.1111/j.1477-9730.2008.00463.x)

Gardner AS and 15 others (2013) A reconciled estimate of glacier contributions to sea level rise: 2003 to 2009. Science, 340 (6134), 852-857 (doi: 10.1126/science.1234532)

Garmin International (2007) GPSMAP 60CSx with sensors and maps: owner's manual. Garmin International Inc., Olathe, KS

Gordon JE, Haynes VM and Hubbard A (2008) Recent glacier changes and climate trends on South Georgia. Glob. Planet. Chang., 60(1-2), 72-84 (doi: 10.1016/j.gloplacha.2006.07.037)

Grosvenor DP, King JC, Choularton TW and Lachlan-Cope T (2014) Downslope föhn winds over the Antarctic Peninsula and their effect on the Larsen ice shelves. Atmos. Chem. Phys., 14(18), 9481-9509 (doi: 10.5194/acp-14-9481-2014)

Hambrey MJ, Smellie JL, Nelson AE and Johnson JS (2008) Late Cenozoic glacier-volcano interaction on James Ross Island and adjacent areas, James Ross Island. Geol. Soc. Amer. Bull., 120, 709-731 (doi: 10.1130/B26242.1)

Hilbert C and Schmullius C (2012) Influence of surface topography on ICESat/GLAS forest height estimation and waveform shape. Remote Sens., 4, 2210-2235 (doi: 10.3390/rs4082210)

Hrbáček F, Láska K and Engel Z (2016) Effect of snow cover on the active-layer thermal regime - a case study from James Ross Island, Antarctic Peninsula. Permafrost Periglac., 27, 307-315 (doi: 10.1002/ppp.1871)

King JC, Turner J, Marshall GJ, Connolley WM and Lachlan-Cope TA (2003) Antarctic Peninsula climate variability and its causes as revealed by instrumental records. In Domack $E$, Leventer $A$, Burnett A, Bindschadler R, Convey $\mathrm{P}$ and Kirby $\mathrm{M}$, eds. Antarctic Peninsula climate variability: historical and paleoenvironmental perspectives. American Geophysical Union, Washington, 17-30 (doi: 10.1029/AR079p0017)

Kropáček J, Neckel N and Bauder A (2014) Estimation of mass balance of the grosser Aletschgletscher, Swiss Alps, from ICESat laser altimetry data and digital elevation models. Remote Sens., 6(6), 5614-5632 (doi: 10.3390/rs6065614)

Kunz $M$ and 6 others (2012) Multi-decadal glacier surface lowering in the Antarctic Peninsula. Geophys. Res. Lett., 39, L19502 (doi: 10.1029/2012GL052823)

Lapazaran JJ, Otero J, Martín-Español A and Navarro FJ (2016) On the errors involved in ice-thickness estimates I: ground-penetrating radar measurement errors. J. Glaciol., 62(236), 1008-1020 (doi: 10.1017/jog.2016.93)

Lirio JM and 6 others (2017) 60 años de retroceso glaciario en Península Potter, Isla 25 de mayo, Islas Shetland del Sur, Antártida. In Guaiquil I, Leppe M, Rojas P and Canales R, eds. Visiones de Ciencia Antártica. Instituo Antártico Chileno, Punta, Arenas, 509-512

MALÅ GeoScience (2005) Ramac GPR. Hardware manual. MALÅ GeoScience, Malå

Marinsek S and Ermolin E (2015) 10 year mass balance by glaciological and geodetic methods of Glaciar Bahía del Diablo, Vega Island, Antarctic Peninsula. Ann. Glaciol., 56(70), 141145 (doi: 10.3189/2015AoG70A958)

Marshall GJ, Orr A, van Lipzig N and King JC (2006) The impact of a changing Southern Hemisphere Annular Mode on Antarctic Peninsula summer temperatures. J. Clim., 19, 5388-5404 (doi: 10.1175/JCLI3844.1)

Mavlyudov BR (2014) Mass balance of the Bellingshausen Ice Dome in 2007-2012 (King George Island, South Shetland Islands, Antarctica). Lyod i sneg, 125(1), 27-34, In Russian

Mavlyudov BR (2016) Bellingshausen Ice Dome, Antarctic. In Kotlyakov VM ed. Problems of geography, geography of polar regions, v. 142. Codex, Moscow, 629-648, In Russian 
Medley B and Thomas ER (2019) Increased snowfall over the Antarctic Ice Sheet mitigated twentieth-century sea-level. Nat. Clim. Change, 9, 34-39 (doi: 10.1038/s41558-018-0356-x)

Meixner P (2009) Mapping in Antarctica. GEODIS News, 8, 8-9

Mernild SH, Lipscomb WH, Bahr DB, Radić V and Zemp M (2013) Global glacier changes: a revised assessment of committed mass losses and sampling uncertainties. Cryosphere, 7(5), 1565-1577 (doi: 10.5194/tc-7-1565-2013)

Molina C, Navarro FJ, Calvet J, García-Sellés D and Lapazaran JJ (2007) Hurd Peninsula glaciers, Livingston Island, Antarctica, as indicators of regional warming: ice volume changes during the period 1956-2000. Ann. Glaciol., 46, 43-49 (doi: 10.3189/ 172756407782871765)

Narod BB and Clarke GKC (1994) Miniature high-power impulse transmitter for radio-echo sounding. J. Glaciol., 40(134), 190194 (doi: 10.3189/S002214300000397X)

Navarro FJ, Jonsell UY, Corcuera MI and Martín-Español A (2013) Decelerated mass loss of Hurd and Johnsons Glaciers, Livingston Island, Antarctic Peninsula. J. Glaciol., 59(213), 115-128 (doi: 10.3189/2013JoG12J144)

Neckel N, Kropáček J, Bolch T and Hochschild T (2014) Glacier mass changes on the Tibetan Plateau 2003-2009 derived from ICESat laser altimetry measurements. Environ. Res. Lett., 9(1), 014009-014009 (doi: 10.1088/1748-9326/9/1/014009)

Nesje A, Bakke J, Dahl SO, Lie Ø and Matthews JA (2008) Norwegian mountain glaciers in the past, present and future. Glob. Planet. Chang., 60, 10-27 (doi: 10.1016/j.gloplacha.2006.08.004)

Oliva M and 7 others (2017) Recent regional climate cooling on the Antarctic Peninsula and associated impacts on the cryosphere. Sci. Total Environ., 580, 210-223 (doi: 10.1016/j.scitotenv.2016.12.030)

Osmanoğlu B, Navarro FJ, Hock R, Braun M and Corcuera MI (2014) Surface velocity and mass balance of Livingston Island ice cap, Antarctica. Cryosphere, 8, 1807-1823 (doi: 10.5194/tc-8-18072014)

Petlicki M, Sziło J, MacDonell S, Vivero S and Bialik RJ (2017) Recent deceleration of the ice elevation change of ecology Glacier (King George Island, Antarctica). Remote Sens., 9(6), 520 (doi: 10.3390/rs9060520)

PGC (2018) The Reference Elevation Model of Antarctica (REMA). User documentation. Polar Geospatial Center, Minnesota

Pudełko R, Angiel PJ, Potocki M, Jedrejek A and Kozak M (2018) Fluctuation of glacial retreat rates in the eastern part of Warszawa Icefield, King George Island, Antarctica, 19792018. Remote Sens., 10(6), 892 (doi: 10.3390/rs10060892)

Rabassa J, Skvarca P, Bertani L and Mazzoni E (1982) Glacier inventory of James Ross and Vega Islands, Antarctic Peninsula. Ann. Glaciol., 3, 260-264 (doi: 10.3189/S0260305500002883)

Rivera A, Casassa G, Bamber J and Kääb A (2005a) Ice-elevation changes of Glaciar Chico, southern Patagonia, using ASTER DEMs, aerial photographs and GPS data. J. Glaciol., 51(172), 105-112 (doi: 10.3189/172756505781829557)

Rivera A and 7 others (2005b) Glacier wastage on southern Adelaide Island, Antarctica, and its impact on snow runway operations. Ann. Glaciol., 41, 57-62 (doi: 10.3189/172756405781813401)

Rückamp M, Braun M, Suckro S and Blindow N (2011) Observed glacial changes on the King George Island ice cap, Antarctica, in the last decade. Glob. Planet. Chang., 79(1-2), 99-109 (doi: 10.1016/j.gloplacha.2011.06.009)

Sandmeier KJ (2017) Reflexw: processing program for seismic, acoustic and electromagnetic reflection, refraction and transmission data, version 8.5. Sandmeier Scientific Software, Karlsruhe

Scambos TA and 6 others (2014) Detailed ice loss pattern in the northern Antarctic Peninsula: widespread decline driven by ice front retreats. Cryosphere, 8, 2135-2145 (doi: 10.5194/tc-8-2135-2014)

SCAR (2019) Composite gazetteer of Antarctica. Scientific Committee on Antarctic Research, Cambridge

Skvarca P and De Angelis H (2003) Impact assessment of regional climatic warming on glaciers and ice shelves of the northeastern Antarctic Peninsula. In Domack EW, Leventer A, Burnett A, Convey $\mathrm{P}$, Kirby $\mathrm{M}$ and Bindschadler $\mathrm{R}$, eds. Antarctic Peninsula climate variability: a historical and paleoenvironmental perspective. American Geophysical Union, Washington, D.C., 69-78

Simões JC, Dani N, Bremer UF, Aquino FE and Arigony-Neto J (2004) Small cirque glaciers retreat on Keller Peninsula, Admiralty Bay, King George Island, Antarctica. Pesq. Antárt. Bras., 4, 49-56

Smellie JL and 7 others (2008) Six million years of glacial history recorded in the James Ross Island Volcanic Group, Antarctic Peninsula. Palaeogeogr. Palaeoclimatol., 260(1-2), 122-148 (doi: 10.1016/j.palaeo.2007.08.011)

Sobota I, Kejna M and Araźny A (2015) Short-term mass changes and retreat of the Ecology and Sphinx glacier system, King George Island, Antarctic Peninsula. Antarct. Sci., 27(5), 500-510 (doi: 10.1017/S0954102015000188)

Trimble Navigation Limited (2013) Trimble Geo $7 X$ handheld: user guide. Trimble Navigation Limited, Westminster, CO

Turner J and 8 others (2004) The SCAR READER project: towards a high-quality databse of mean Antarctic meteorological observations. J. Climate, 17, 2890-2898 (doi: 10.1175/1520-0442 (2004)017<2890:TSRPTA > 2.0.CO;2)

Turner J and 8 others (2005) Antarctic climate change during last 50 years. Int. J. Climatol., 25, 279-294 (doi: 10.1002/joc.1130)

Turner J and 9 others (2016) Absence of 21st century warming on Antarctic Peninsula consistent with natural variability. Nature, 535(7612), 411-415 (doi: 10.1038/nature18645)

van Lipzig NPM, King JC, Lachlan-Cope TA and van den Broeke MR (2004) Precipitation, sublimation, and snow drift in the Antarctic Peninsula region from a regional atmospheric model. J. Geophys. Res., 109, D24106 (doi: 10.1029/2004JD004701)

WGMS (2018) Fluctuations of glaciers database. World Glacier Monitoring Service, Zurich (doi: 10.5904/wgms-fog-2018-06)

Wouters B and 7 others (2015) Glacier mass loss. Dynamic thinning of glaciers on the Southern Antarctic Peninsula. Science, $\mathbf{3 4 8}$ (6237), 899-903 (doi: 10.1126/science.aaa5727)

Zekollari H, Huybrechts P, Noël B, van de Berg WJ and van den Broeke MR (2017) Sensitivity, stability and future evolution of the world's northernmost ice cap, Hans Tausen Iskappe (Greenland). Cryosphere, 11, 805-825 (doi: 10.5194/tc-11-805-2017)

Zemp M and 38 others (2015) Historically unprecedented global glacier decline in the early 21 st century. J. Glaciol., 61(228), 745-762 (doi: 10.3189/2015JoG15J017) 